\title{
Helen Salisbury: A hostile environment in the NHS
}

\author{
Helen Salisbury GP \\ Oxford
}

A temporary resident recently attended our practice after coughing up blood. The likely cause was pneumonia, but tuberculosis and malignancy were on the list of differential diagnoses. My colleague duly sent the patient for chest radiography, but the request was refused as the patient-a visitor to this country-did not have an NHS number. We were told that radiography would be possible if the patient attended the emergency department.

This is surely dangerous. From a public health perspective, highly infectious diseases-in this case possible open tuberculosis-must be diagnosed and treated as swiftly as possible. Primary care is available to everyone in the UK, so I don't understand why chest radiography requested by a GP is not counted as part of that primary care.

Most doctors and most patients don't know the rules: you do not need identity documents or proof of address or immigration status to register with a GP and access care. We need to educate all practices and their reception teams about this; there are some excellent resources online including the Safer Surgeries Initiative. $^{1}$

Under current law in England, hospital care must be paid for if you are not "ordinarily resident" in the UK, but there are exemptions: care given in emergency departments is free. Investigation and treatment of many infectious diseases are not chargeable. Some vulnerable groups are also exempt from charging. ${ }^{2}$ So even if the immigration status of our patient was uncertain, they should still have been offered an x ray examination.

Although the concept of charging overseas visitors for NHS care has a long history, the mechanisms to enforce these charges have been strengthened as part of the government's hostile environment policy, designed to make life for undocumented migrants living in the UK untenable. Some hospitals have gone as far as putting up posters advising patients that they may not be eligible for free care and introducing identity checks for people who could not convince staff of their UK residency. ${ }^{3}$
This is a recipe for racism-as a white woman with received pronunciation, I doubt I would be questioned, but what if I had darker skin or a different accent?

Some well publicised disasters have resulted from these rules, such as the man charged $£ 54000$ ( $€ 60000 ; \$ 65000)$ for cancer care despite being resident in the UK for 44 years. ${ }^{4}$ There are many more instances of patients being denied care because they cannot pay or failing to access it through fear of being charged. ${ }^{45}$

The BMA called on the government to publish the findings of its own review into the effects of migrant charging, which it launched back in 2017, but this request has been denied. ${ }^{6} \mathrm{We}$ can only assume that this is because the results confirm what clinicians at the front line already know-that mistakes, injustice, and avoidable suffering have been caused not for financial benefit, but merely to help the government look tough on immigration. As doctors, we must continue to speak out against this policy, which harms us all: vulnerable people are denied care, public health is compromised, and the founding ethos of the NHS is undermined.

Doctors of the World. Safe surgeries toolkit. https://www.doctorsoftheworld.org.uk/whatwe-stand-for/supporting-medics/safe-surgeries-initiative/safe-surgeries-toolkit/\#

Department of Health and Social Care. Overseas NHS visitors: implementing the charging regulations. 2018. https://www.gov.uk/government/publications/overseas-nhs-visitorsimplementing-the-charging-regulations

3 De A. Barts Health Trust scraps immigration checks for patients following wide scale protests. East London Lines 26 Sep 2018. http://www.eastlondonlines.co.uk/2018/09/ barts-health-trust-scraps-immigration-checks-for-patients-following-wide-scale-protests/

4 Gentleman A. Theresa May refuses to intervene over man's $£ 54,000$ NHS cancer bill. Guardian 22 Mar 2018. https://www.theguardian.com/uk-news/2018/mar/22/theresa-mayrefuses-to-intervene-over-mans-54000-nhs-cancer-bill-albert-thompson

5 O'Donnell K, Abubakar I, Aldridge R, et al. Transparency is needed on NHS charges for migrants and data sharing agreements. BMJ Opinion 13 May 2019. https://blogs.bmj.com/ bmj/2019/05/13/creating-a-hostile-environment-for-migrants-transparency-is-needed-onnhs-charges-and-data-sharing-agreements-in-nhs-england/

6 BMA. BMA says charging regulations for overseas patients are threatening the quality of NHS care. 18 Apr 2019. https://www.bma.org.uk/news/media-centre/press-releases/2019/ april/bma-says-charging-regulations-for-overseas-patients-are-threatening-the-quality-ofnhs-care

Published by the BMJ Publishing Group Limited. For permission to use (where not already granted under a licence) please go to http://group.bmj.com/group/rights-licensing/ permissions 